\title{
INJURIES TO THE CERVICAL SPINE SUSTAINED WHILE CARRYING LOADS ON THE HEAD
}

\author{
By A. T. Scher, M.B., Ch.B., D.M.R.D. \\ Spinal Cord Injuries Unit, Conradie Hospital, Cape Town, South Africa
}

Abstract. The level and type of injury in I2 patients with cervical spinal cord injury as a result of accidents while carrying heavy loads on the head is analysed. Lateral radiographs of the cervical spine in subjects loaded with $200 \mathrm{lb}$ bags on the head, to assess the effects on the normal configuration of the spine, were obtained. Radiological assessment of a further group of labourers with long periods of this type of employment was done in an attempt to demonstrate any increased predisposition to osteo-arthrotic change in the cervical spine.

Key words: Negroid race; Spinal cord injury; Industrial medicine.

\section{Introduction}

IT is a common practice amongst many of the Black (South African Negro) tribes of South Africa to carry objects both heavy and light on their heads. This they do with great ease and without any apparent conscious effort at balancing these objects. The origin of this mode of transportation is unknown. It is strictly confined to the Black tribes and is not found amongst the Coloured (mixed breed) people of South Africa. One of the possible reasons for this practice is that it is a desirable physical attribute for women to have an erect, straight-backed posture. Carrying objects on the head assists in the development of a good posture. Children at a young age begin to carry objects on their heads in imitation to their elders. It is the women who usually carry loads (particularly bundles of firewood) on their heads, since according to tribal custom, such duties are beneath the dignity of men. Figures I and 2 illustrate such activities.

In industry and agriculture, however, it is the men who carry sacks of grain and other products on their heads. The maize and wheat sacks are particularly heavy, weighing $200 \mathrm{lb}$. This type of unskilled labour is done almost exclusively by the Blacks, both for socio-economic reasons and because they have the ability and strength to perform this arduous work for hours on end.

The labourer does not lift the bag himself, this being done by two or four of his co-workers, who lift the bag, while the labourer walks underneath the bag, steadies it on his head with his hands and walks to the unloading point.

Recently a patient with acute traumatic tetraplegia sustained while carrying a bag of maize, was admitted to the Spinal Injuries Unit. This patient although a young man, showed radiological evidence of gross osteo-arthrosis of the cervical spine. This observation stimulated interest in this type of injury and also into the effects on the cervical spine of carrying these heavy loads, particularly as regards the occurrence of any premature osteo-arthrotic changes.

\section{Material and Methods}

The X-rays and case histories of all patients admitted to the unit with cervical spinal cord injuries sustained while loading bags, or while carrying other objects 


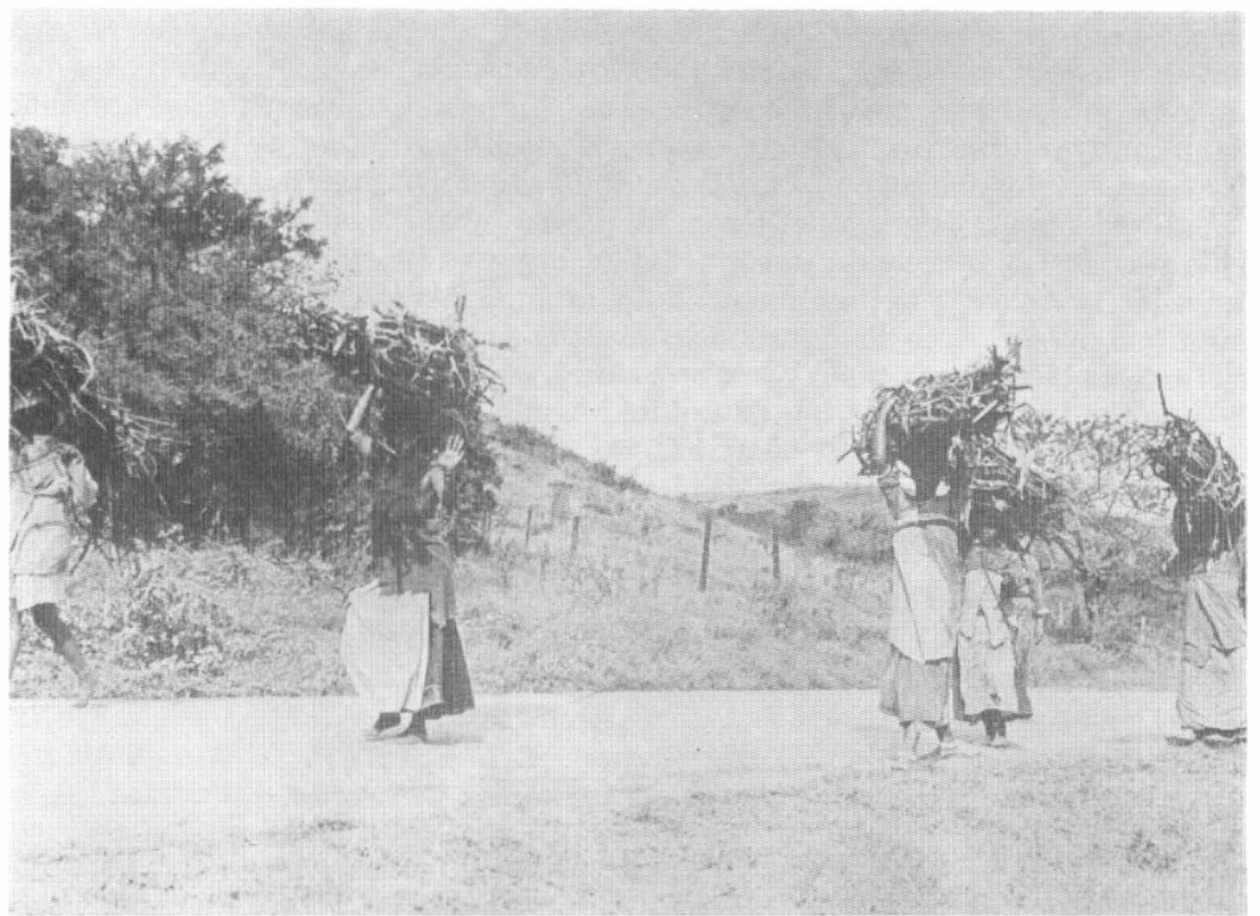

FIG. I

Women carrying bundles of firewood.

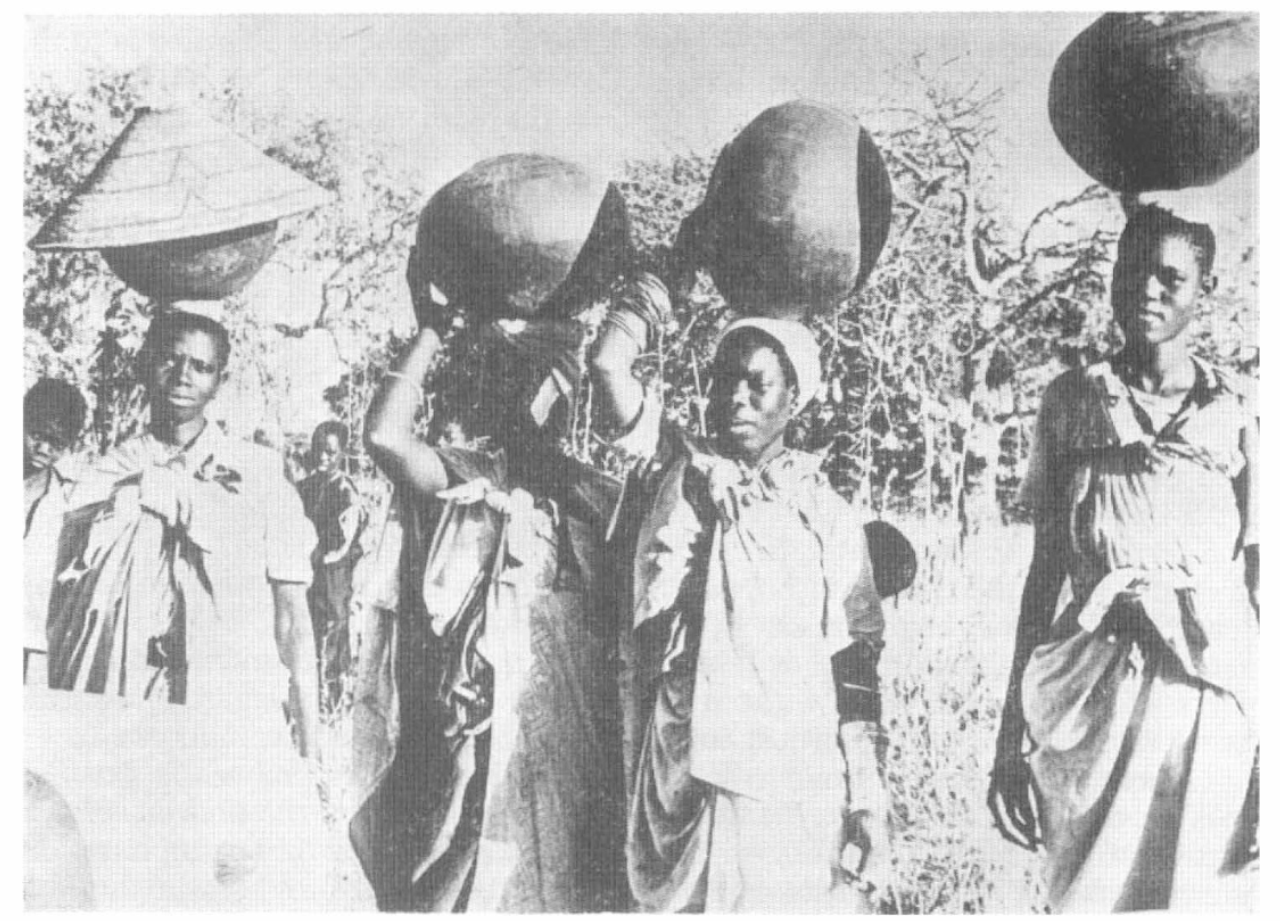

FIG. 2

Women carrying pots on the head. 
on the head, were reviewed. A small number of patients had sustained fractures and/or dislocations of the thoraco-lumbar spine with paraplegia, after bags had fallen on to their backs while being stacked. This group of patients did not differ significantly in orthopaedic injury or clinical condition from other patients injured by heavy weights falling on to the back, and were not further analysed.

Two lateral radiographs of the cervical spine were obtained on eight subjects. Firstly at rest and secondly after a $200 \mathrm{lb}$ bag was placed on their heads. All the subjects were in good health and had no complaints referable to the neck, apart from one subject who had sustained an extensive stab wound into the anterior soft tissues of the neck some years previously.

As the bag is steadied by the uplifted hands, the subject's arms obscured the cervical spine on the lateral view. It was therefore necessary for the hands to be moved slightly forward, so as to clear the arms from the cervical spine. Levy (I968) in a similar study does not indicate how this technical difficulty was overcome.

The presence of osteo-arthrotic changes of the cervical spine was assessed radiologically in an additional 20 subjects. Their ages ranged from 28 to 45 years. All were experienced in this form of work, having carried bags for periods ranging from 7 to 15 years.

\section{Incidence}

The incidence of cervical spinal cord injuries, consequent upon injury sustained while carrying objects on the head, cannot be assessed. In theory all patients with acute spinal cord injury in the Cape Province (the largest of the four provinces of South Africa) should be referred to this unit. Some patients, however, die before they can be transferred to the unit, while others are occasionally treated in other hospitals. It is also impossible to obtain accurate figures as to the number of labourers engaged in this type of work. The incidence would, however, appear to be remarkably low. Only 12 patients with such cervical spinal cord injuries have been admitted during the period 1964-76, while millions of bags are handled annually by thousands of labourers. There are also hundreds of thousands of Black women carrying objects on their heads at all times.

\footnotetext{
Results

Analysis of Injuries

The anatomical site of, and type of injury are shown in Table I. The level of injury was predominantly at the $\mathrm{C}_{4}-\mathrm{C}_{5}$ and $\mathrm{C}_{5}-\mathrm{C}_{6}$ levels. No injuries of the upper cervical spine above $\mathrm{C}_{4}$ were recorded, in contrast to the findings of Levy (I968) where injuries of the upper cervical spine were predominant.

Analysis of the type of orthopaedic injury shows that flexion-rotation injuries were most common, being present in 8 ( 66 per cent) of the patients. These injuries manifested as either unilateral or bilateral locking of facets, or as anterior displacements of a vertebral body without dislocation. The remaining four patients showed evidence of either vertical compression or hyperextension injury.

Three patients were women who had stumbled or tripped while carrying loads on their heads. This type of accident is facilitated by the uneven terrain, absence of paved roads and hilly country in which many of these people reside. Injury sustained while actually carrying a bag occurred in only two of the nine male patients. The remaining seven males were injured as a result of faulty
} 


\section{TABLE I}

Distribution and type of injury in $\mathbf{2} 2$ cases of cervical spinal cord injury sustained with heavy loads on the head

\begin{tabular}{|c|c|c|c|c|c|c|}
\hline & $\begin{array}{l}\text { Bilateral } \\
\text { locked } \\
\text { facets }\end{array}$ & $\begin{array}{l}\text { Unilateral } \\
\text { locked } \\
\text { facets }\end{array}$ & $\begin{array}{l}\text { Anterior } \\
\text { subluxation }\end{array}$ & $\begin{array}{l}\text { Compression } \\
\text { fracture of } \\
\text { vertebral } \\
\text { body }\end{array}$ & $\begin{array}{c}\text { Fracture of } \\
\text { spinous } \\
\text { process }\end{array}$ & $\begin{array}{l}\text { No radiographic } \\
\text { evidence of } \\
\text { injury }\end{array}$ \\
\hline $\mathrm{C}_{4}$ & - & - & - & - & - & - \\
\hline $\mathrm{C}_{4}-\mathrm{C}_{5}$ & 2 & - & 2 & - & - & - \\
\hline $\mathrm{C} 5$ & - & - & - & 2 & I & I \\
\hline $\mathrm{C}_{5}-\mathrm{C} 6$ & I & I & - & - & 一 & - \\
\hline C6 & - & - & - & - & - & - \\
\hline C6-C7 & I & - & $\mathbf{I}$ & - & - & - \\
\hline
\end{tabular}

lifting of the bag on to their heads by their colleagues, or slipping of a bag off the stack on to the head.

The neurological deficit associated with these injuries was severe. In II (92 per cent) of the 12 patients, there was complete tetraplegia with permanent loss of motor and sensory function below the level of the lesion. In only one patient was the tetraplegia incomplete.

\section{$X$-Ray Examination of the Cervical Spine at Rest and Under Stress}

Analysis of the 'resting' lateral views of the eight volunteer subjects demonstrated that six subjects had a normal cervical lordosis, while two showed straightening of the cervical spine. Weir (I975), in an assessment of the normal appearance of the cervical spine on lateral X-ray, found a straight spine in 20 per cent of normal subjects. He also noted that when the subjects depressed their chins by one inch, straightening of the normal cervical lordosis occurred in 70 per cent of normal subjects.

Analysis of the lateral views after loading the $200 \mathrm{lb}$ bag on to the head, showed that six of the subjects had developed some degree of flexion deformity, with acute kyphotic angulation localised to one disc space in three subjects. In only two subjects (one of whom had a straight spine at rest) did straightening of the spine occur. Levy (1968) in a similar study found that the majority of his subjects developed a straight spine when loaded. Figures 2 to 6 demonstrate the findings in four subjects.

\section{Presence of Osteo-arthrosis}

Diagnosis of osteo-arthrosis was made on the presence of one or more of the following criteria.

Osteophytes arising from the anterior or posterior borders of the vertebral bodies, disc space narrowing and osteo-arthrosis of the neuro-central joints. Evidence of osteo-arthrotic change was present in only three subjects. The changes were not marked and radiologically would be classified as being of an early nature only. The three subjects affected were in the older age group, one being $4 \mathrm{I}$ years old and the other two 44 years of age. 


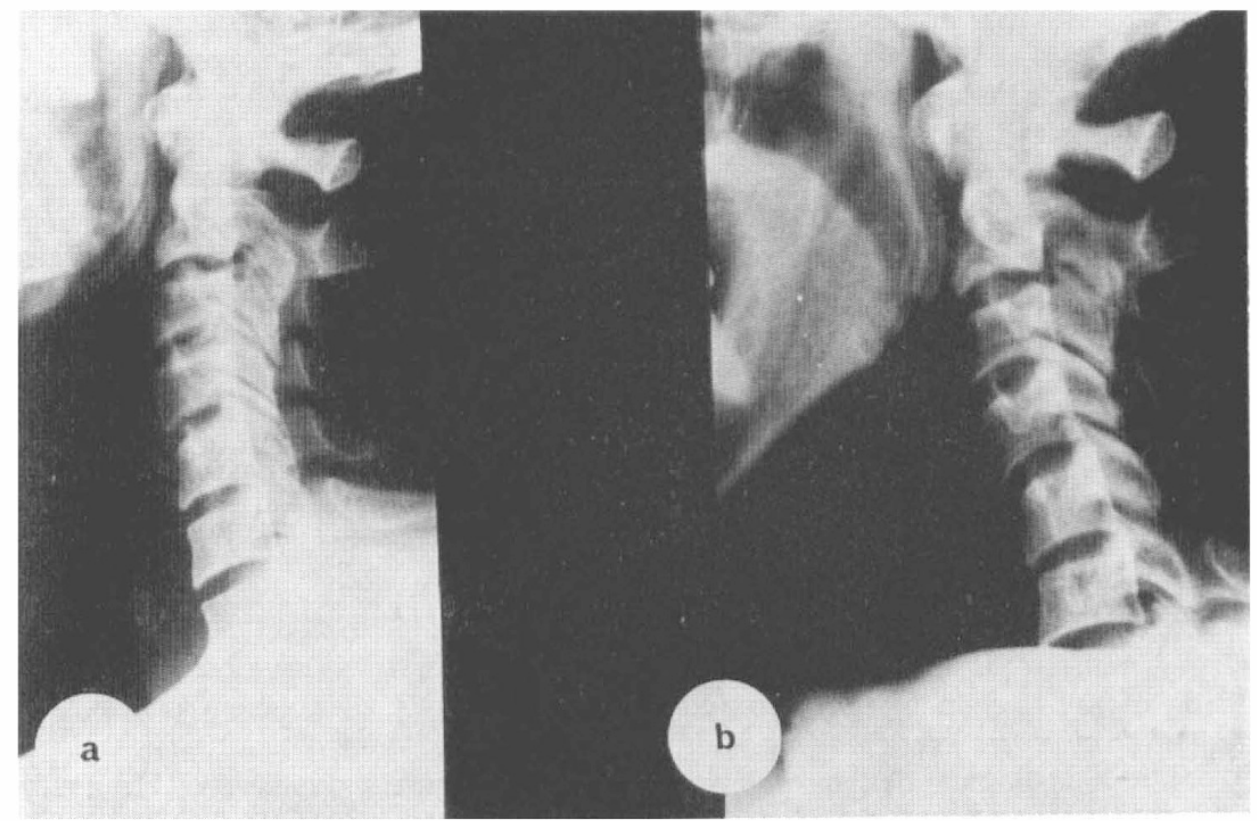

Fig. 3a

Cervical spine at rest.
FIG. $3 \mathrm{~b}$

Cervical spine after loading with $200 \mathrm{lb}$ bag on head. Flexion with slight kyphotic angulation at $\mathrm{C}_{4} / \mathrm{C}_{5}$ level.

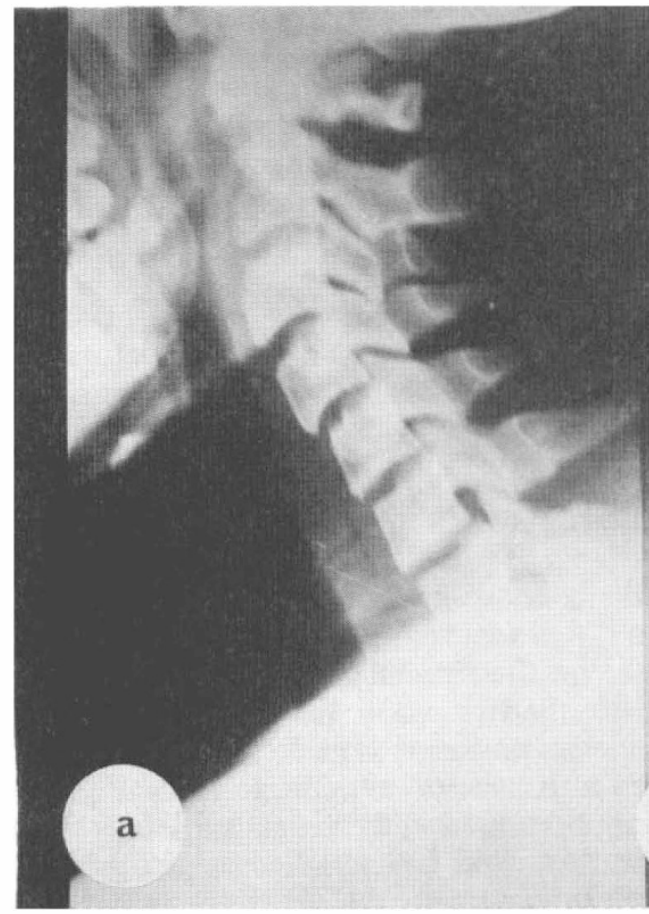

FIG. 4a

Cervical spine after loading with $200 \mathrm{lb}$ bag on head. Flexion and slight angulation at $\mathrm{C}_{4} / \mathrm{C}_{5}$ level.

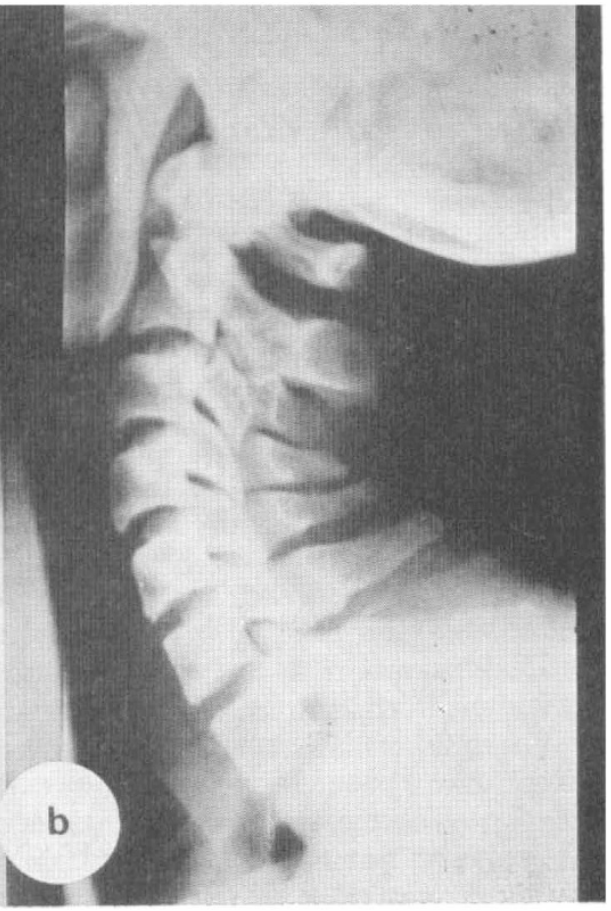

FIG. 4b

Cervical spine at rest. 


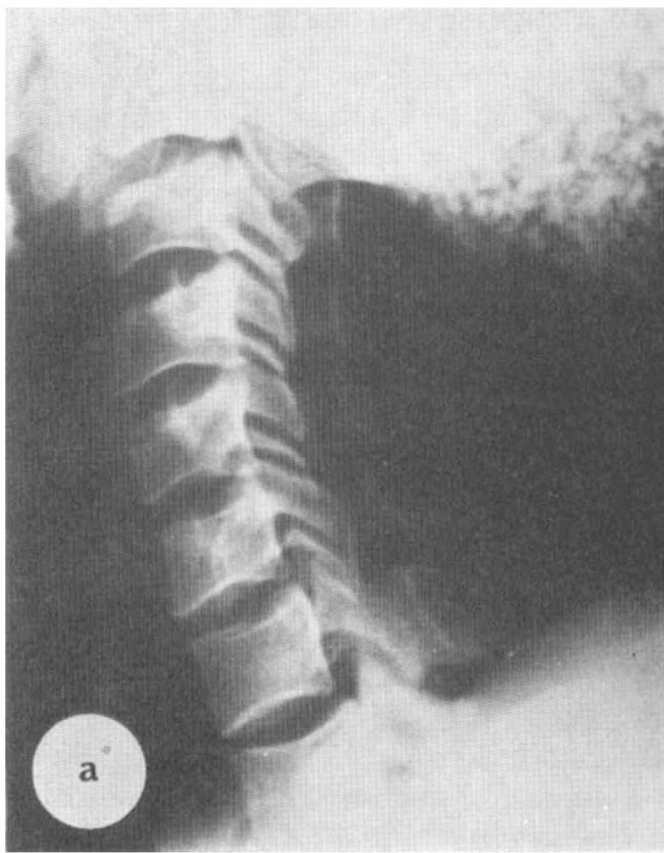

Fig. 5a

Cervical spine after loading with $200 \mathrm{lb}$ bag on head. Part of the bag and its contents are shown. There is subluxation at the $\mathrm{C}_{7} / \mathrm{TI}_{\mathrm{I}}$ apophyseal joints.

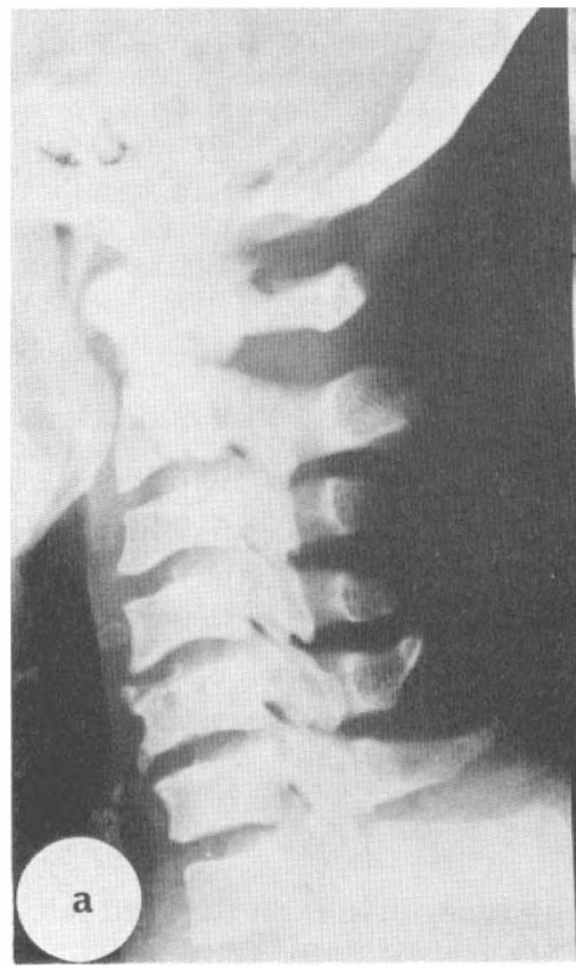

FIG. 6a

Cervical spine at rest.

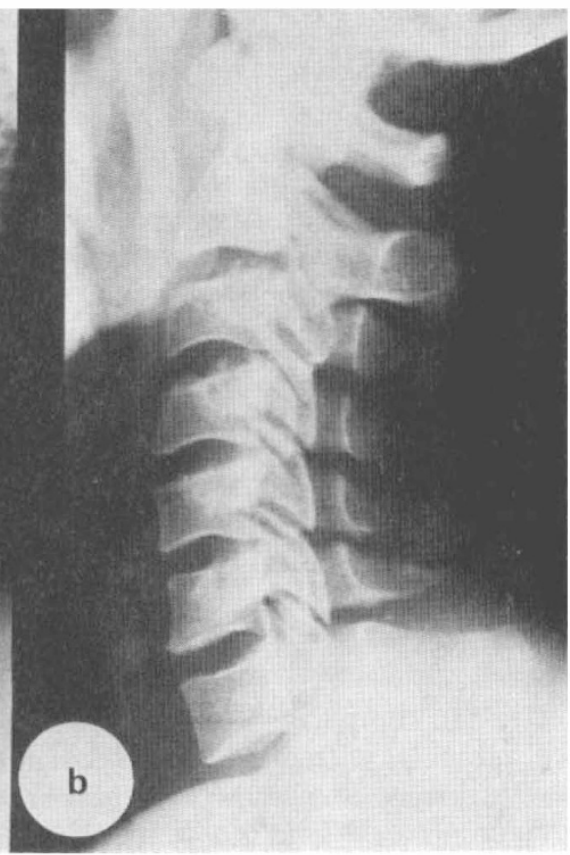

Fig. 5b

Cervical spine at rest.

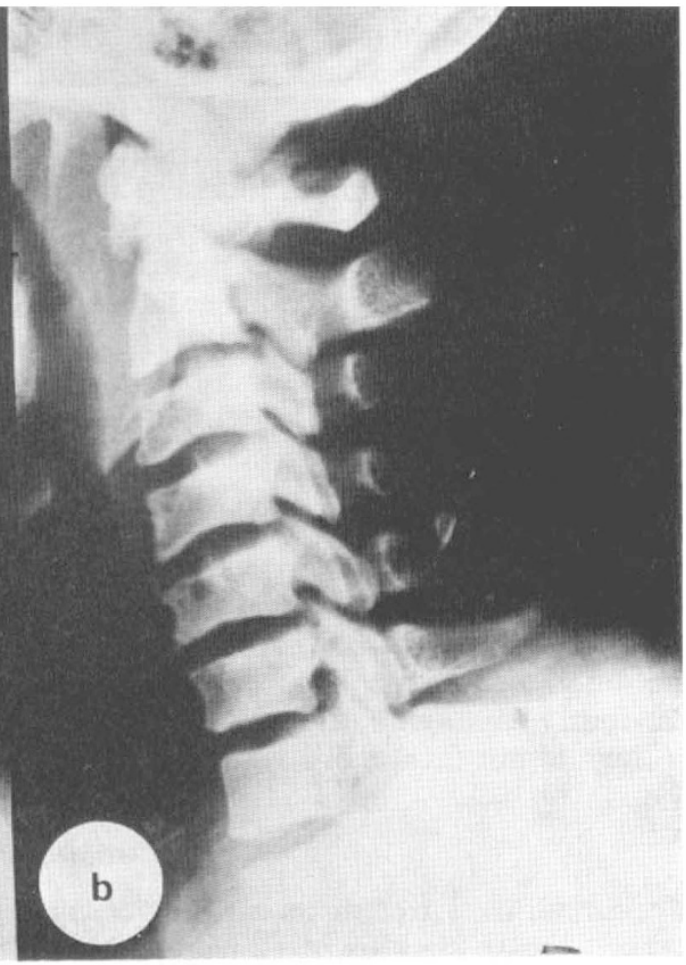

Fig. 6b

Cervical spine after loading with $200 \mathrm{lb}$ bag. No significant change in position. 


\section{Discussion}

Mechanism of Injury

The observation that a flexion deformity was present in the majority of subjects X-rayed under stress, would suggest that they are particularly liable to flexion injuries. This is confirmed by the preponderance of flexion injuries present in the series of patients analysed. With the cervical spine in an already abnormally flexed position, tripping or stumbling will tend to throw the sack forward. As Levy (1968) has pointed out, the head of the victim is embedded in the sack as it sags slightly on the head under the great weight. Should the sack be thrown forward at the moment of tripping, the head must follow. The findings that the majority of injuries occurred at the $\mathrm{C}_{4}-\mathrm{C}_{5}$ and $\mathrm{C}_{5}-\mathrm{C} 6$ levels is not surprising. The lower cervical spine is the site of predilection for cervical spinal cord injuries, whatever the cause. The $\mathrm{C}_{4}-\mathrm{C}_{5}$ and $\mathrm{C}_{5}-\mathrm{C}_{6}$ segments are the most mobile areas of the lower cervical spine (Penning, 1964).

\section{Incidence of Osteo-arthrosis}

True comparison of the prevalence of osteo-arthrosis of the cervical spine in our subjects, with the incidence of males of similar ages, in different occupations cannot be made. Over the age of 50 radiological evidence of osteo-arthrosis is very common. The incidence of these changes in adults under the age of 50 has not been established.

There are also racial differences in the incidence and distribution of osteoarthrosis. There is a marked difference in the pattern of joint involvement in the Blacks, as compared to the White. For example the hip joint which is commonly affected by osteo-arthrosis in the Whites, is seldom affected in the Black population (Solomon et al., 1975). There are also differences in joint mobility in different ethnic groups. Negroes and Indians have been shown to have a greater degree of joint mobility than White South Africans (Beighton et al., 1973). Lumbar disc disease is rarely encountered in the Blacks, despite their involvement in heavy manual labour in industry and mining. Levy (1967), in an attempt to establish the causes for the low incidence of disc disease in the Blacks, demonstrated that there was greater mobility of the lumbar spine in the Blacks as compared to the Whites. He also compared the incidence of degenerative disease of the cervical and lumbar spine in elderly Blacks and Whites, finding no significant difference between the two groups. He postulates that manual labour strengthens rather than weakens the musculature and ligamentous supports of the back and thereby reduces the likelihood of disc degeneration.

Bearing all the above factors in mind, accurate assessment of the relevance of the incidence of osteo-arthrotic change, in the subjects examined, is not possible. It is our impression, however, that the carrying of heavy objects on the head does not predispose to premature osteo-arthrosis of the cervical spine. An exception was the patient mentioned in the introductory remarks. This patient was the only person in the series who was not a Black, being a Coloured; as previously mentioned, they are not normally employed in this type of occupation, as they do not favour this type of employment.

\section{Conclusion}

Spinal cord trauma as a result of carrying heavy objects on the head rarely occurs. In an analysis of 12 patients with cervical spinal cord injury consequent 
upon such accidents, flexion injuries are seen to predominate. Radiographic examination of the cervical spine on subjects loaded with a $200 \mathrm{lb}$ bag on the head, shows that the spine is forced into a position of flexion deformity by the weight. This finding correlates with the observation that the majority of tetraplegia patients in our series showed orthopaedic evidence of flexion injury. That this type of injury occurs infrequently is fortunate, since severe neurological deficit accompanies these injuries.

Despite the stress on the cervical spine caused by years of carrying heavy bags on the head, there would not appear to be an increased predisposition to osteo-arthrotic change. Racial differences in patterns of osteo-arthrosis and joint mobility make comparison with other groups of people not exposed to this type of stress difficult.

\section{RÉSUMÉ}

Le geure de lésions et leur intensité est analysé chez 12 patients qui souffrent de lésions du cordon médullaire cervical causées par un accident lors du transport de poids lourds sur leur tête. Des radios latérales de la colonne cervicale de sujets dont la tête était chargée de sacs 200 livres ont été obtenues pour évaluer l'effet d'un poids sur la colonne cervicale à l'état normal. L'étude radiologique à été faite d'un autre groupe de travailleurs après des années de ce geure de travail pour essayer de démontrer une prédisposition supérieure quelconque pour un changement vers une arthose des os dans la colonne cervicale.

\section{ZUSAMMENFASSUNG}

Die Position und Art der Halswirbelverletzungen bei I2 Patienten als Folge von Unfällen, während schwere Lasten auf dem Kopf getragen warden, wird analysiert. Seitliche Röntgenaufnahmen der Halswirbel wurden gemacht von Testpersonen die IOO kg Säcke auf ihrem Kopf trugen, um die Wirkung auf die normale Rückgratshaltung zu erlangen. Röntgenuntersuchungen mit weiteren Arbeitergruppen, die lange Zeit diese Art Arbeit verrichtet halten, wurden gemacht um vergrösserte Empfänglichkeit für 'osteoarthrotic' Veränderung der Halswirbel zu demonstrieren.

\section{REFERENCES}

Beighton, P., Solomon, L. \& Soskolne, C. L. (I973). Articular mobility in an African population. Annals of Rheumatic Diseases, 32, No. 5, 23.

Levy, L. (1967). Lumbar intervertebral disc disease in Africans. F. Neurosurg. 26, 3 I.

LeVy, L. (1968). Porter's neck. Brit. Med. F. 2, i6.

Penning, L. (1964). Nonpathologic and pathologic relationships between the lower cervical vertebrae. Amer. F. Roentgenol., 91, 1036.

Solomon, L., Beighton, P. \& LAwrence, J. S. (I975). Rheumatic disorders in the South African Negro. S. Afr. Med. F. 49, I 737.

WeIR, C. D. (1975). Roentgenographic signs of cervical injury. Clinical Orthopaedics and Related Research, No. I09, 9. 